\title{
Paridades y conflictos: Analogía de dos mundos en La Celestina de Teatro El Público
}

\author{
Dania del Pino Más \\ Consejo Nacional de las Artes Escénicas, Cuba
}

Desde que en el verano de 1990 el director Carlos Díaz Alfonso presentara para la escena cubana la trilogía de teatro norteamericano conformada por los títulos Te y simpatía de Robert Anderson y Zoológico de cristal y Un tranvía llamado deseo de Tennessee Williams, los montajes de Teatro El Público - como se haría llamar el grupo oficialmente dos años despuéshan estado marcados en la acogida del público y la crítica por una notable contradicción: desde el más radical rechazo o cuestionamiento de algunos, hasta la alabanza, el deslumbramiento y la aceptación de otros. Los espectadores que se enfrentan a las obras de este colectivo deliran en una activación de múltiples sentidos, de la que nunca pueden salir ilesos. Este delirio se instala muchas veces en los contextos cotidianos, propiciando fructíferos y polémicos debates entre la crítica y la intelectualidad nacional cubana. Las razones son obvias: la sustentabilidad de un discurso transgresor, erigido sobre la base del artificio poético, siempre con un elevado sentido espectacular, grandilocuente y muchas veces agresivo, en el que se dislocan los conceptos de realidad y ficción, lo cómico y lo trágico, lo femenino y lo masculino; y que se enfrenta, una y otra vez, a tabúes y normas sociales. Lo interesante es que, muchas veces, esa subversión de la realidad presente en las puestas en escena de Carlos Díaz parte de un referente textual clásico, reelaborado dramatúrgicamente en función de un contexto y un concepto artístico contemporáneos. Hacia la década del 90, a pesar de que la isla sufría la más profunda crisis económica de los últimos cincuenta años, el teatro cubano gozaba de plena salud. Se mantenían activos colectivos como Teatro Estudio, con Vicente Revuelta a la cabeza, que desde décadas anteriores constituía paradigma del arte escénico en el país no sólo por una práctica sostenida con importantes resultados artísticos sino también por su función de formación de actores y directores. Una práctica similar la había comenzado en los 80 Flora Lauten con el Teatro Buendía en el marco del Instituto Superior de Arte, que rompió con los métodos convencionales de actuación promovidos en 
la Academia por profesores soviéticos. Teatro del Obstáculo, con Víctor Varela, apostó por su parte por un teatro sagrado, cercano al ejercicio ritual, indagando en los posibles principios de una escritura postmoderna y asumiendo el trabajo del actor a partir de presupuestos artaudianos (Muguercia 2007: 3-27). Del Buendía brotarían luego colectivos como Argos Teatro, dirigido por Carlos Celdrán, o El Ciervo Encantado, con Nelda Castillo como líder, que han desarrollado poéticas particulares a la par de Teatro El Público. Hacia aquellos 90 estaba también Teatro Irrumpe, una verdadera escuela para Carlos Díaz, en la cual, bajo la tutela de Roberto Blanco, se había desempeñado como diseñador y asistente de dirección.

Lo que comenzó a construir Teatro El Público desde los 90 constituye una explosión poética en todos sus niveles. En aquellos años compartía espacio con grupos como Teatro Estudio, Irrumpe, Buendía, Teatro del Obstáculo, DanzAbierta Danza Contemporánea de Cuba y otros grupos que prometían también subvertir algunos cánones sociales y escénicos. Pero la irrupción de Teatro El Público en la escena nacional constituyó la subida al escenario de un erotismo severo, de desenfreno y revolución sexual, de crítica mordaz e irónica, justo en un contexto que, «bajo la presión de un lapso de paralizador cierre económico - como diría el crítico y dramaturgo cubano Norge Espinosa- y la crisis de una ideología que llegamos a suponer invulnerable, se nos exigía posturas cada vez menos inocentes en el arte, que es decir, también, en la vida» (Espinosa Mendoza 2002: 14). Lo cierto es que Carlos Díaz se instaló desde entonces y para siempre en la historia teatral cubana y llegó a alcanzar en 2015 el Premio Nacional de Teatro que otorga el Ministerio de Cultura, la Unión Nacional de Escritores y Artistas de Cuba, y el Consejo Nacional de las Artes Escénicas. Se integró «de forma irreverente a la tradición, asumiendo la festividad del hecho escénico con carácter de desmesura sensual, en un posmodernismo que podría catalogarse de posbarroco si lo traducimos a nuestro devenir cultural» (Cano 2002: 114). Con ese mismo principio de desmesura que se hizo luego recurrente tras aquella trilogía inicial, llegaron nuevos títulos y clásicos: Las criadas de Jean Genet, La niñita querida de Virgilio Piñera, El Público de Lorca, Calígula de Camus, Escuadra hacia la muerte de Sastre, El rey Lear de Shakespeare, La Celestina de Rojas, La puta respetuosa de Sartre y Fedra de Racine. Asimismo, se escenificaron también obras de autores nacionales, como Norge Espinosa o Rogelio Orizondo, con quienes el diálogo ha adquirido matices particulares que han permitido experimentar una especie de dueto creativo, siempre poniendo sobre el tapete las problemáticas más urgentes de una Cuba festiva y edulcorada pero, al mismo tiempo, cruda y dolorosa en sus más profundas esencias.

Curiosamente fue La Celestina de Fernando de Rojas la obra que provocó las mayores polémicas. En el 2002, tras ciento cincuenta funciones ininterrumpidas, se convirtió en el más importante éxito de público en los últimos diez años de la escena cubana, donde alcanzar más de cin- 
cuenta presentaciones es una verdadera proeza debido a la escasez de salas teatrales y la elevada cantidad de colectivos teatrales existentes. La importancia de esta obra para la consolidación de Teatro El Público se expresa así en su sitio web:

En la historia de toda compañía teatral que logre pervivir
una cierta cantidad de años, hay un antes y un después,
no sólo en términos estéticos, sino también en el orden
de impacto en sus espectadores, multiplicándolos has-
ta un nivel impensable. Un suceso, como diría la prensa
sensacionalista. Eso fue, indudablemente, La Celestina
para Teatro El Público. ${ }^{1}$

Efectivamente La Celestina no constituyó un acontecimiento sólo por su cantidad de funciones ni por las cifras estadísticas que evidenciaban su éxito, sino especialmente por la movilización provocada en el público más heterogéneo ante lo que acontecía en el escenario. En saludo al quinto centenario de la escritura de la obra primigenia, Carlos Díaz decidió acercarse a esta historia de fervientes pasiones para releer «los criterios de moralidad, fortuna, amor, desvarío y muerte de un período humano, y mostrar los suyos» (González Melo 2002: s-p).

Mi investigación estudia los mecanismos de apropiación del texto clásico que supone la re-contextualización de personajes harto conocidos y de todo un universo simbólico puesto a funcionar en el espectáculo para establecer analogías y conflictos entre dos mundos: el universo medieval en el que Rojas escribió su obra y el ámbito contemporáneo en el que fue presentada por Teatro El Público ante los aforos de la isla. Pretendo analizar los recursos fundamentales que permiten al director dicha actualización a través de la dramaturgia textual y espectacular: la caracterización de los personajes, la carnavalización, el trabajo con los referentes locales y universales, los diseños de vestuario, luces y escenografía, y el despliegue de recursos como la parodia, el desnudo y el travestismo. Como paso previo, es preciso establecer un concepto de dramaturgia que nos permita entender ese ejercicio de rescritura. Especialmente adecuado es el del teórico y estudioso francés Patrice Pavis, quien define la dramaturgia de la siguiente manera:

[E]l conjunto de las opciones estéticas e ideológicas que el equipo de realización, desde el director de escena al actor, ha llevado a cabo. [...] Establece el estatuto ficcio-

1.- <http://www.teatroelpublico.cult.cu/Dossier/La\%20Celestina.html>, consultado el 3 de enero de 2016. En este mismo sitio web se ofrece la posibilidad de adquirir un DVD con la representación de la obra, así como la posibilidad de descargar el texto de la adaptación en formato de texto. Desafortunadamente, la galería de imágenes que aparece como un enlace no está activa en la fecha en que se consultó. Sin embargo, se pueden ver algunas imágenes y el programa de una puesta en escena de 2011 de esta producción en <http://celestinavisual. org/items/show/642>. 
nal y el nivel de realidad de los personajes y de las acciones; configura el universo dramático mediante recursos visuales y auditivos, y decide lo que el público considerará real, es decir, verosímil para él. (Pavis 1998: 148-49)

Este concepto ayuda a comprender el proceso mediante el cual es organizada y estructurada la puesta en escena y, en este caso, el proceso mediante el cual un clásico es reelaborado sobre el escenario en función de un contexto, un equipo de trabajo y un público específicos. Por otro lado, desde su experiencia práctica, el director colombiano Santiago García, fundador del grupo de creación colectiva La Candelaria, considera que la dramaturgia "es el conjunto de elementos que componen un espectáculo teatral o el teatro, entendido como la relación espacio-temporal que se sucede entre la escena y el público». Precisa que es también «el conjunto de textos que conforman el espectáculo teatral en su confrontación con el público, uno de los cuales es el texto literario» (García 2008: 159 y 68). Aunque las definiciones anteriores estén formuladas a partir de las experiencias distintas de la práctica y la teoría, ambas apuntan hacia una noción de la dramaturgia como un producto híbrido en el que se enlazan los distintos lenguajes de la puesta en escena a fin de producir un espectáculo que interactúe con el espectador. Dentro de ese entramado de lenguajes cohabitan los discursos formales, conceptuales, textuales e ideológicos que permiten exponer ideas y temas al público. Las reflexiones de Pavis y García evidencian que el término dramaturgia alude no sólo a la producción del texto dramático, sino también a lo que Eugenio Barba ha llamado la «dramaturgia orgánica»:

\section{[L]a fuerza que mantiene juntos los diferentes compo- nentes de un espectáculo, transformándolo en experien- cia sensorial. La dramaturgia orgánica está constituida por la orquestación de todas las acciones de los actores consideradas como señales dinámicas y cenestésicas. (Barba 2010: 57)}

A partir de estas nociones podemos analizar dos elementos que me parecen fundamentales en el montaje de Calos Díaz. Primero, que $\mathrm{La} \mathrm{Ce-}$ lestina de Fernando de Rojas sirve de fuente textual sobre la cual se erige una nueva escritura y se configura otro universo dramático. El original no es puesto en boca de los actores tal cual fuera escrito por su autor, pero aun así, el texto de Rojas contiene aquello que Dubati llama en la literatura una "teatralidad en potencia» (Dubati 2005: s-p). ${ }^{2}$ Esa teatralidad será

2.- Dubati reflexiona en torno a las diferencias existentes entre teatro y literatura, basándose en la idea esencial de que la escena implica acción física, constituyendo una cultura viviente de la cual prescinde la literatura en tanto existe más allá de un carácter presencial o de interacción. 
llevada a sus máximas consecuencias en el espectáculo de Carlos Díaz. La Celestina, como «texto pre-escénico» (de primer grado), está dotado de cierta virtualidad escénica $y$, aunque fue escrito con anterioridad e independencia del espectáculo, "guarda un vínculo transitivo con la puesta» (Dubati 2005: s-p). Y es justamente en ese proceso de transitividad donde el equipo de realización de Teatro El Público establece las conexiones con el universo ideológico, temático, sintáctico y mágico-religioso del contexto en el cual se creó la obra, es decir, el Medievo y los principios del Renacimiento o Modernidad Temprana. En segundo lugar, la dramaturgia orgánica de la que habla Barba adquiere una relevancia especial en la producción de Teatro El Público. La virtualidad escénica del texto de Rojas es convertida por Carlos Díaz en experiencia sensorial. Por tanto, más allá de estudiar el texto creado por los dramaturgos Norge Espinosa Mendoza y Abel González Melo, quienes estuvieron a cargo de escribir la nueva versión, intentaré acercarme a la puesta en escena para analizar las maneras en las que ha sido actualizado este clásico en pos de generar nuevas posibles lecturas y sentidos en el público receptor, así como las conexiones que entre ambos universos permite establecer esta experiencia estética.

\section{De la España de Rojas a La Habana del siglo XXI: rescribir un clásico}

Norge Espinosa Mendoza y Abel González Melo en ocasiones anteriores habían trabajado con el grupo y por ello conocían su poética teatral. Su vínculo con el colectivo era lo suficientemente sólida como para que supieran bien de qué elementos del texto original podían prescindir. Esta familiaridad y confianza con el trabajo del colectivo les permitió convertir una obra que fuera concebida para ser leída en voz alta entre un grupo de amigos, según nos dice el prólogo del texto rojano, en una producción dramática para ser representada sobre la escena por el grupo teatral. La versión del texto de Melo y Espinosa mantiene, a grandes rasgos, el argumento del texto original. Sin embargo, lo primero que salta a la vista del lector-espectador es la reelaboración de un discurso textual que, si bien gozaba de teatralidad y riqueza en el diálogo, fue escrito, ante todo, para ser enunciado. Por eso, el trabajo dramatúrgico partió de la modificación de los códigos lingüísticos del castellano antiguo del original a un español cercano a las normas más contemporáneas. Al mismo tiempo, se evitaba desviar la atención del público con los extensos monólogos y diálogos del texto rojano, con lo que se intentaba, además, ganar en condensación de la acción dramática y el conflicto. Aun así, los autores respetan las marcas lingüísticas que diferencian a los personajes, las formas de saludar de cada uno y otros modismos que son importantes para los actores en el 
proceso de interpretación de sus personajes. El inicio mismo de la obra puede ofrecernos un ejemplo de cómo se hizo esta adaptación. En el texto original rojano, el encuentro entre Melibea y Calisto tiene lugar de la siguiente manera:

CALISTO.- En esto veo, Melibea, la grandeza de Dios.

MELIBEA.- ¿En qué, Calisto?

CALISTO.- En dar poder a natura que de tan perfecta hermosura te dotase y hacer a mí, inmérito, tanta merced que verte alcanzase y en tan conveniente lugar que $\mathrm{mi}$ secreto dolor manifestarte pudiese. Sin duda incomparablemente es mayor tal galardón que el servicio, sacrificio, devoción y obras pías que por este lugar alcanzar tengo yo a Dios ofrecido, ni otro poder mi voluntad humana puede cumplir. ¿Quién vio en esta vida cuerpo glorificado de ningún hombre como ahora el mío? Por cierto los gloriosos santos, que se deleitan en la visión divina, no gozan más que yo ahora en el acatamiento tuyo. Más ¡oh triste!, que en esto diferimos: que ellos puramente se glorifican sin temor de caer de tal bienaventuranza y yo me alegro con recelo del esquivo tormento que tu ausencia me ha de causar.

MELIBEA.- ¿Por gran premio tienes esto, Calisto?

(Rojas 1977: 46)

En la versión de Teatro El Público, la disertación de Calisto ha sido sintetizada en pos de una condensación de la acción, al tiempo que se han actualizado los códigos lingüísticos para que sean entendidos por el espectador contemporáneo pero sin perder su alto sentido poético. La nueva versión enfoca el diálogo en el interés de Calisto por Melibea, que da inicio a la línea argumental de la historia:

CALISTO: En esto veo, Melibea, la grandeza de Dios.

MELIBEA: ¿En qué, Calisto?

CALISTO: En dar poder a la Naturaleza que de tan perfecta hermosura te dotó, y hacerme indigno de la merced que es verte, para que mi secreto dolor pudiese al fin manifestarse.

MELIBEA: ¿Por gran premio tienes éste, Calisto?

(Espinosa Mendoza y González Melo 2002: 2)

En un pacto respetuoso con las esencias más profundas de la escritura celestinesca y partiendo de la edición de carácter filológico de la editorial Crítica (Rojas y «Antiguo Autor» 2000), esta nueva Celestina recoge toda 
la hibridez y ambigüedad que encierra el original. En esta nueva versión están presentes desde la tradición medieval y renacentista hasta los preludios de la novela picaresca y elementos del barroco que paso a las Américas. El afán didáctico-moralizante medieval sigue vivo en esta versión al mantenerse la muerte de Calisto como castigo al quebrantamiento de las normas sociales y religiosas. Sin embargo, Carlos Díaz lo lleva a escena con una ironía que se burla de la condición aleccionadora implícita en la literatura del Xv. Aunque en la nueva versión se mantiene el universo religioso y el castigo divino a consecuencia del pecado, hay un evidente cuestionamiento del sentido de la existencia, así como se manifiesta la crisis de la fe religiosa. En la versión de Espinosa y Melo y en la escena de Carlos Díaz, la muerte funciona como castigo o destino que cuestiona el sentido de la existencia y su lógica, al tiempo que propicia la exaltación de los instintos y emociones humanas, potenciando el nihilismo ya de por sí presente en el original rojano.

En la segunda parte del Acto I han sido eliminados largos parlamentos de Calisto y Sempronio. Las referencias al mundo clásico y la filosofía medieval han sido obviadas por los adaptadores. Sin embargo, la nueva versión mantiene las protestas de Sempronio por someter «la dignidad del hombre a la imperfección de la mujer» (Espinosa Mendoza y González Melo 2002: 2) como una forma de evidenciar un conflicto de género anclado en el mito bíblico que llega vivo a la sociedad contemporánea, aunque se prescinda de las largas reflexiones que en torno al tema incluye el texto original. Igualmente, desde este diálogo entre Sempronio y Calisto se establece la constante fundamental que desarrollará la nueva versión y el espectáculo de Teatro El Público:

SEMPRONIO: Digo que Dios no quiera tal, que es herejía lo que ahora dijiste.

CALISTO: ¿Y a mí qué?

SEMPRONIO: ¿Tú no eres cristiano?

CALISTO: ¿Yo? Melibeo soy y a Melibea adoro y en Melibea creo y a Melibea amo. (3)

La respuesta de Calisto a la pregunta de Pármeno contiene el conflicto fundamental que mantiene la reescritura de Teatro El Público: el dilema entre el placer y el deber cristiano. La desacralización de los comportamientos morales de la época a partir de una vulgarización del universo religioso, la utilización de los apartes para ridiculizar convenciones triviales de la incipiente burguesía y el deseo carnal como principal motor de la conducta humana son traídos del original para tomar cuerpo sobre la escena.

Visto desde la realidad de la sociedad cubana contemporánea, Espinosa y Melo emplean estos diálogos como una denuncia crítica de la doble moral asentada en muchos espacios oficiales de la isla, de los falsos 
dogmas sociales y religiosos que imponen a la gente el uso de máscaras para evitar ser juzgados, castigados o mal vistos por la colectividad. Con esto me estoy refiriendo a las connotaciones morales que pueden tener para el individuo cubano algunos grupos sociales organizados, como los espacios de representación colectiva, en los que la individualidad se ve muchas veces amenazada. Y aquí se vislumbra otra característica común entre la España del siglo XIV y la Cuba del XXI: las maneras de sociabilidad. Como bien apunta Asenjo González:

[L]as formas de asociaciones horizontales más elementales de la etapa medieval eran la amistad y la vecindad. Si la primera precisaba del afecto y el trato mutuo, la segunda se desarrollaba en un parámetro más distante pero siempre entendido como resultado de la proximidad y de la ayuda. (2008:17)

De la misma manera, en la Cuba contemporánea, y desde hace algunos años, la solidaridad deviene un valor elemental, resultado en muchas ocasiones de las carencias y problemas económicos del país desde los años 90 y el llamado Período Especial. El vecino y el amigo son recibidos en muchos casos con un trato familiar que evidencia muchas veces el quebrantamiento de los límites convencionales de las relaciones humanas. Así, en la nueva versión del texto rojano se han mantenido las frases familiares que usan los personajes para acercarse a su interlocutor y buscar en el otro una verdadera complicidad correspondientes a las relaciones de vecindad y familiaridad medieval. Oímos a Pármeno interpelar a Celestina: "Madre, háblame, que solo quiero oírte y creerte». De manera similar, Calisto se dirige familiarmente la alcahueta: "Ve ahora, madre, y consuela tu casa: y después ven, y consuela la mía» (8). El uso de la palabra «madre» por parte de estos jóvenes no sólo indica la diferencia de generación o de nivel jerárquico que, en cuestiones de administradora de placeres, tiene Celestina por encima de los demás personajes, sino que también evidencia una parodia del universo religioso a través de los bien conocidos paralelismos entre Celestina y la Madre Celestial. El uso de este apelativo resuena también a las muy cercanas formas de interacción entre los cubanos actuales. Por ejemplo, Calisto dice en otro momento de la obra: «Hermanos míos, cien monedas di a la madre. ¿Hice bien?» (8). Permanece así en la nueva versión la referencia cristiana a los hombres como hijos de Dios — «hermanos»—, que es uno de los apelativos más comunes en Cuba. En la isla, el uso de "hermano» trasciende no sólo el marco religioso inicial sino también los espacios más íntimos de socialización para constituirse en una manera popular de apelar a desconocidos o personas menos allegadas. 


\section{El cuerpo y el placer: la más celestinesca de las puestas en escena}

Esta atribución de nuevos o dobles sentidos de las palabras originales no es el fundamento del carácter rompedor de esta versión. Existía el problema de lograr una verdadera transgresión, la subversión de un clásico que era ya en sí mismo un salto al vacío, un grito de libertad que rompía con las convenciones de su tiempo. Ante esta dificultad, el único espacio posible para materializar esta subversión estaba no tanto en el texto en sí como en los cuerpos en escena, en la revalorización del placer y el espíritu festivo que entre líneas propone La Celestina, en la posibilidad de vivir una experiencia donde el público compartiera espacios de libertad. Para lograr una transgresión real, la dramaturgia espectacular a cargo del equipo de realización apeló al desnudo como arma principal. Los cuerpos erguidos sobre las tablas se enroscaban continuamente en una coreografía que no pretendía ser juego de simulaciones sino encarnación de lo que subyacía en el texto originario: la debilidad de la carne como castigo perenne para los hombres, el cuerpo sobre el alma, la lucha interminable entre la razón y el deseo. La Celestina de Carlos Díaz expone de manera directa el universo erótico recreado por de Rojas en la obra primigenia, tratando «de entender el juego de pasiones de la obra como un suceso profanable y cercano» (Espinosa Mendoza, «el otro hilado»: s-p). Podría decirse que esta puesta en escena materializa los deseos latentes pues en ella se recrea el universo erótico que Celestina reclama y evoca todo el tiempo en el texto de Rojas. La alcahueta, ante la imposibilidad de obtener su propio placer debido a su avanzada edad, propicia los encuentros carnales y se alimenta del placer ajeno. Como sostiene Galarreta-Aima, «este placer mediado a través del goce ajeno está íntimamente vinculado con los sentidos de la vista, el oído y el tacto» (2011: 44). Y es precisamente en esa intencionalidad de Celestina donde radica el principal matriz de teatralidad del cual se apropiará Carlos Díaz. El teatro, como «acto de convivio» (Dubati, "Cultura teatral»: s-p) implica compartir una vivencia entre la escena y la platea a través de la activación de los sentidos.

Los espectadores que participan en las funciones de esta puesta en escena asisten a la realización de los deseos más profundos de la alcahueta a través de las constantes interacciones de los cuerpos de los actores. Las pesadas vestimentas medievales son arrancadas a la vista del espectador, como despojando el plumaje de esas aves deseosas, para decirlo casi con las palabras del personaje de Calisto durante el encuentro en el jardín con Melibea. Encontramos al ser humano desnudo, como lo muestra el Génesis y lo representan las artes plásticas a través de los siglos. En una especie de paraíso, Calisto/Adán y Melibea/Eva, —y véanse también estos duetos como analogías de dos universos- vuelven a pecar por al- 
canzar el placer, despojándose de toda culpa y obedeciendo a sus más profundos instintos. Vuelve aquí uno de esos vínculos transitivos entre el original y la puesta en escena que está implícito en la palabras de Areúsa al inicio del auto xIv, rescatado por Melo y Espinosa en la nueva versión y materializado teatralmente en el montaje de Carlos Díaz: «Ruin sea quien por ruin se tiene, que en un final somos todos hijos de Adán y Eva» (19). Melibea, semidesnuda por su jardín/escenario, como una Eva en su propio paraíso, experimenta las más fuertes emociones en su incondicional amor por Calisto. Lo que en un pasado bíblico fuera génesis del mundo, imagen inmaculada del surgimiento de la vida, es ahora releído bajo la mirada medieval y contemporánea como un momento de deleite, defendiendo la tesis de que el amor de Adán y Eva contenía un alto sentido carnal. Nos encontramos así ante una relectura de la cosmovisión cristiana y occidental, ante una reflexión en el tiempo en torno a la dualidad cuerpo / alma. Pero lo más interesante es que Carlos Díaz establece un juego de ilimitadas confluencias temporales que son evidenciadas en el espectador a través de los recursos formales con los que trabaja. En la obra, si bien los cuerpos muchas veces permanecen desnudos, a Celestina se la mantiene siempre vestida. A partir del marcado contraste entre su largo ropaje y los cuerpos desnudos de los otros personajes se vislumbran las rupturas de una época, la medieval, que es cuestionada por quienes la reconstruyen sobre el escenario presente. Una mirada al pasado desde un momento actual que tiene sus propias flaquezas.

Celestina es la encarnación de esta ruptura a través de varias contradicciones que encarna en su personaje: es blasfemia y humanidad, poder y sumisión, religión y herejía, el conocimiento y la ignorancia, lo culto y lo popular, lo femenino y lo masculino. La gestualidad marcada y las exquisitas transiciones de la actriz cubana que la interpretó, Paula Alí, llevan desde el más imponente de los tonos hasta los consejos e insinuaciones más melodiosas que suavizan su carácter a medio camino entre víctima y victimaria. En la Cuba de 2002, como lo hiciera en la España de su tiempo, Celestina se aprovecha de las crisis de fe que atraviesan los hombres, de la necesidad de acudir a potencias superiores para lograr sus propias metas, y de sus ansias de placer. Y en ambas geografías se refuerzan ideas individualistas propias del tránsito del medioevo al Renacimiento, vigentes también en la actualidad más inmediata, cuando el consumismo adquiere dimensiones impensables. Las características del capitalismo burgués encarnadas en el personaje clásico, su actitud materialista y la mentalidad práctica con que se mueve a lo largo de la obra se mantienen en la puesta en escena de Teatro El Público. El personaje de Celestina despliega una retórica capaz de persuadir a sus interlocutores. Esa habilidad es potenciada en el ejercicio interpretativo a partir de una enunciación que siempre recurre a un tono convincente, que añade matices de seducción a través de la mirada y la complicidad del público, 
siempre en pos de conseguir su propio beneficio. Pero, presentada ante el espectador cubano, esta actitud individualista e interesada adquirió una nueva dimensión. En la Cuba que vio La Celestina de Teatro El Público, la crisis económica imponía actitudes cada vez más descarnadas, al punto de propiciar estafas y manipulaciones igualmente perversas para alcanzar riquezas y bienes materiales. Y es justo en la corrupción del personaje y su deseo de enriquecimiento donde la puesta en escena de Carlos Díaz alcanza también carácter político. El director pone ante los ojos del público un comportamiento que ha sido condenado históricamente, incluso por la literatura. Celestina es condenada en el original por su propio autor. Su muerte constituye el castigo moralizante de quien ha faltado a las normas sociales establecidas de la España medieval. En su puesta en escena, Carlos Díaz busca la complicidad del público para colocarlo en el mismo plano de la alcahueta, para recordarle que ha faltado igualmente a la moral en busca de su propio beneficio: lo convierte, como a Celestina, en víctima y victimario del sistema social al cual pertenece y lo coloca ante un conflicto ético y humano.

La imagen grotesca que proyectan las pobladas cejas y el encrespado y negro cabello con que se ha caracterizado a Celestina en esta puesta en escena forma parte de una estética del transformismo que se extiende también a varios de los personajes. Y es que la voluptuosidad de los cuerpos trasciende incluso su identidad sexual. Las debilidades de la carne trascienden toda categoría y definición exacta, y hombres y mujeres se aman sin ambages, en sus más amplios niveles de existencia. En el episodio del Acto VII Celestina manosea el cuerpo desnudo de Areúsa y dice: — «Bendígate Dios y señor san Miguel, ángel! ¡Y qué gorda y fresca que estás! ¡Qué pechos y qué gentileza»-. La connotación homoerótica de este parlamento es convertido en un elemento tautológico de la puesta en escena. Igualmente, los hombres se tocan entre sí, se miran, buscando constantemente una complicidad sexual basada en el disfrute pleno, de la misma manera que lo hacen los personajes femeninos. Géneros e identidades múltiples nos hablan de una naturaleza similar: la del amor. Esto iguala a los personajes en algunos aspectos, como sucede en el original, a pesar de sus distintos niveles sociales. Se crea así un nuevo sentido en la obra. Si bien en la Cuba contemporánea la diferencia de clases no es tan marcada como en el mundo de Rojas, los tabúes en torno a la aceptación de la homosexualidad, el transformismo y la cultura gay en general son generalmente muy fuertes. Por eso, el similar tratamiento que da Carlos Díaz a las relaciones homosexuales y heterosexuales en la obra viene a ocupar el espacio que en el original rojano corresponde a las clases sociales. El espectáculo nos llama hacia una aceptación basada en el respeto a lo diverso.

En esta puesta en escena, elementos propios del mundo medieval devienen juguetes sexuales, símbolos de un universo sexualizado que no acepta límites. De esta forma, una espada se convierte fácilmente en un 
símbolo fálico con el que los actores simulan masturbaciones y otros juegos eróticos, mientras que una soga sirve para propiciar escenas de sometimiento sexual, activándose así fetiches e imaginarios múltiples. De esta forma, se recurre a imágenes que evocan la relación entre el dolor y el placer, imágenes que transmiten al espectador insinuaciones de flagelación erótica, amplificando la idea del disfrute sexual e incluso del amor. En su diálogo con Melibea en el Acto x, Celestina define el amor como "un fuego escondido, una agradable llaga, un sabroso veneno, una dulce amargura, una delectable dolencia, un alegre tormento, una dulce y fiera herida, una blanda muerte» (Rojas 1977: 235). De esta forma, la alcahueta establece los vínculos entre el amor y la dolencia, entre, sufrimiento y deleite, disfrute y sometimiento. Esta conexión la crea Carlos Díaz en el plano corporal en su puesta en escena atendiendo a que las nociones de Celestina sobre al amor no se distancian en ningún punto de las cuestiones de la carne. Igualmente sucede con el espejo en el cual una de las actrices se contempla semidesnuda. Aquí vuelve a ser el cuerpo, en ese ejercicio de mirarse a sí mismo, objeto incitador y canalizador del placer de manera simultánea, materia e idea.

Celestina dialoga con demonios y mortales, colocándolos a un mismo nivel. Se mueve de uno a otro dominio, como si en su figura se conectaran estos dos universos, el terrenal y el sagrado, el material y el utópico. Reforzando esta continuidad, la puesta en escena acerca la brujería medieval a los cultos sincréticos de la religión cubana, a sus practicantes y al misticismo de la isla. Celestina aparece vestida de rojo y negro como Eleggua, el primero de los cuatro guerreros del panteón yoruba, junto a Ogun, Ochosi, Ozun y Orunmila. Es Eleggua, el que abre los caminos, el que controla los reinos del bien y del mal, el que logra balancear ambas fuerzas sobre las que tiene dominio. Como esta deidad heredada de los esclavos africanos de la Cuba colonial, Celestina se ocupa de limpiar los senderos pasionales por donde se desplazan los otros personajes, moviéndose con confianza entre ambos universos. Para el espectador cubano de La Celestina de Carlos Díaz, la identificación de Celestina con Eleggua se ve reforzada por el hecho de que Eleggua es una deidad conocida por su tendencia a hacer trampas, una deidad que, a través de sus maniobras, logra mover los hilos del futuro, como la vieja alcahueta. Como ella, los creyentes de las religiones afrocubanas conversan con sus dioses cual si fueran amigos, los invocan, tratan de convencerlos, e incluso les amenazan si no cumplen, como hace Celestina al exigir a Plutón "a que venga [...] sin tardanza para obedecer [mi] voluntad", y no bastándole, agrega, "si no lo haces, me tendrás por tu mayor enemiga, heriré con luz tus cárceles oscuras y acusaré cruelmente tus continuas mentiras» (6). Es más, Celestina recuerda también al espectador cubano la figura de Babalawo, un adivinador y oficiante de la religión yoruba; ella encarna a los hombres de todos los tiempos que han pervivido entre 
nosotros haciendo de sus brebajes un oficio y tornando las miserias del mundo en un negocio provechoso.

La verdadera maestría de la reescritura de Norge Espinosa, Abel González Melo, Carlos Díaz y el resto del equipo radica en dejar la muerte de la protagonista en la penumbra. Escribe Norge Espinosa: «Dejé en manos del director la idea de que ese fantasma se perpetuara más allá de su caída y que, de algún modo, el espectador siguiera sintiendo su presencia en el escenario, moviendo - ahora una Parca más - los hilos de la fatalidad» ( EEl otro hilado»: sp). Por eso, después de que se produce el apuñalamiento de Celestina en el Acto XII, la actriz Paula Alí —-todavía vestida como el personaje de Celestina - vuelve a atravesar el escenario en dos ocasiones, recordando a los otros personajes que su destino ha sido trazado y que no hay vuelta atrás. Pero más allá de esta lectura, que no es en ningún caso vertical, la verdadera suerte de Celestina pasa así a manos del espectador, a quien le toca reconstruir un espacio indeterminado, un futuro posible para la alcahueta con quien inevitablemente se han identificado, dado el carácter real, profundamente humano y ambiguo de ésta. Son ellos quienes deberán decidir el destino del personaje, que viene a ser, de alguna forma, el destino de una isla sobre la cual comienza a abalanzarse la corrupción como forma de vida, pero también la búsqueda del amor y el placer como caminos posibles hacia la felicidad.

El tratamiento de los otros personajes celestinescos propicia también una relectura histórica en los planos estético y formal. El director acude a diferentes estilos de representación heredados de las más variadas prácticas teatrales para construir la dramaturgia de los actores. El tono narrativo de algunos de los parlamentos, combinados con los numerosos apartes y la inserción de temas musicales que apoyan el argumento como otro nivel narrativo, son matizados con un cierto tono festivo-juglaresco que busca propiciar la complicidad participativa del espectador, como se supone ocurría en los espectáculos medievales. El montaje revisita además elementos de Commedia dell'arte, en la cual aparecen los personajes-tipo de los criados y los enamorados. En ella se apoya Carlos Díaz para crear esta mascarada con un estilo que es definitorio de los espectáculos de Teatro El Público, y que contribuye a resaltar el sentido de doble moralidad de muchas sociedades actuales y que caracterizaba también a la del siglo XV. Este mensaje es reforzado por una interpretación que es quebrada constantemente por el desdoblamiento del actor en más de un personaje a través de una marcada impostación de la voz, propia de los actores de corrales, y que resalta el plano ficcional. Se acentúa así el tono paródico de la puesta en escena no sólo para hablar de un pasado histórico sino también de la evolución de una estética de la actuación. Otro estilo interpretativo, mucho más contenido e íntimo, se usa para distanciar al espectador de la parodia y así validar los discursos de Melibea antes de su suicidio y el planctus de Pleberio. La confesión de Melibea de su amor por 
Calisto y el discurso final de Pleberio contienen una sinceridad absoluta y reflejan la lectura que del texto hace el director. Si bien por un lado las palabras de Melibea resaltan la pureza de sus sentimientos, el discurso de Pleberio evidencia su frustración como padre y no pueden ambos dejar de ser vistos como símbolos de la frustración del cubano contemporáneo, que cuestiona el sentido de su propia existencia ante el arrebato de sus aspiraciones y sueños.

Otros ingredientes de la puesta en escena contribuyen a dar nuevos significados al texto. Así, por ejemplo, vestimentas de espectáculos anteriores se han reciclado intencionalmente para este espectáculo. La referencialidad de estas vestimentas no puede pasar desapercibida. Están allí, cohabitando de manera silenciosa, el espectro de El Rey Lear de Shakespeare junto con algunos demonios de El Público de Lorca. El poder de Lear y lo erótico y hermoso de El Público acompañan los ademanes de los actores, se inscriben en sus cuerpos a través del ropaje y evidencian las cercanías estéticas de Fernando de Rojas con autores tan sensuales como Shakespeare o Lorca, o el propio Camus y su Calígula, con su delirio por alcanzar la luna, inconforme, como la Celestina, ante un mundo que no sacia sus propios deseos. Pero además de los subrepticios hilos que tejen la dramaturgia de los actores, el diseño musical nos habla de otros vínculos con la Edad Media y los siglos inmediatos. La música que acompaña al espectáculo remite al espectador a un ambiente renacentista presente ya en el texto de Rojas. La música muchas veces acompaña a los actores cuando emiten expresiones del bufo y el choteo cubano que remarcan, por su contraste evidente con el resto del texto, el sentido paródico del espectáculo. Todo ese universo, combinado con temas musicales clásicos y folclóricos de la cultura española como el cuplé y el pasodoble, dialoga con ritmos y sinfonías cubanas, como la décima guajira, o el tema de Bola de Nieve Por qué me la dejaste querer, en el cual el autor reclama a Dios por arrebatarle a su amada, o La Natilla del grupo Habana Abierta, que se erigía por aquel entonces como uno de los éxitos en la música de la isla.

Pero si bien esa mixtura sonora encierra en sí misma la imbricación de dos universos y trae a un mismo plano lo culto y lo popular, la combinación de la música clásica con reminiscencias del teatro cubano popular lo hace todavía más rico y evidente. Son insertados en medio de esas partituras recursos de los bufos cubanos (piezas breves de partes habladas con pasajes musicales de corte ligero y amable del XIX) que incorporan aspectos de la vida cotidiana y de los conflictos sociales más urgentes de la isla. El choteo y el kitsch se erigen no sólo como un homenaje a las grandes figuras del bufo cubano sino también como reflexiones de una historia teatral de la isla. La palabra hablada abandona muchas veces el carácter conversacional y adquiere un tono de discurso que encierra una crítica mordaz de figuras y contextos políticos. Sobre el escenario, los actores, como si estuvieran subidos en una tribuna o podio, lanzan con- 
signas y arengas que, si bien no son una crítica por el contenido del texto - casi siempre meros parlamentos del texto de Rojas- sí lo hacen desde los matices de su enunciación: la acción es recalcada por la cadena física del actor en su plano gestual, que muchas veces distancia al público de la fábula para acercarlo a personajes-tipo de los escenarios nacionales.

Apunta en la misma dirección el diseño escenográfico de Alain Ortiz y Carlos Díaz, que otorga un sentido lúdico al espectáculo. Cual rompecabezas, los actores lo reconfiguran una y otra vez. Los personajes se mueven, se paran, bailan, cantan o emiten largos parlamentos como si estuvieran en una maqueta de arquitectura medieval. El hombre contemporáneo revisita su historia, su pasado, juega con los castillos que antaño constituían también símbolos de encierro y de la moralidad de una época. Pero los decorados tienen además detalles de la heráldica habanera, aludiendo a los muros sobre los que se levanta Teatro El Público para hablar de Cuba en un ejercicio de verdadera transgresión. Y en esa misma representación arquitectónica vuelve a leerse un pasado heredado de un proceso de colonización que comienza, significativamente, en los mismos años que Fernando de Rojas escribió su texto. Este juego con pequeños espacios en los cuales los actores representan la acción, muchas veces de manera simultánea, guarda también conexiones con el teatro antiguo y su carácter sacro. Si revisitamos la rudimentaria escenografía de la España de los siglos inmediatamente anteriores y posteriores a Rojas, descubrimos escenarios móviles en forma de carretas sobre las cuales se hacía la representación por diferentes puntos de la ciudad; había también escenarios estáticos que se dividían en dos variedades fundamentales: la primera de estas consistía en escenarios independientes colocados en diversos puntos de la ciudad; la segunda era conocida como escena simultánea:

[C]onsistía [...] en un largo tablado, el cual se subdividía en pequeños locales, cada uno indicativo de un lugar diferente. Recibían el nombre de mansions. Los actores se movían de una mansión a otra, lo que a veces significaba que viajaban ante los ojos de los encantados espectadores. (Nieves Rivera y Henríquez Hureña 1990: 15)

Igualmente, en esta puesta en escena de La Celestina vemos lo que se puede definir como pequeños escenarios simultáneos, en los cuales siempre existe acción. Con esta variante se reconstruyen desde la arquitectura de la época hasta las alcobas de los personajes. Pero incluso más allá de esta analogía en la disposición de la escena, existe también una conexión entre el mundo en que nació La Celestina y la puesta en escena de Teatro El Público en la concepción de los niveles escénicos. En la España de esos siglos, en las representaciones eran habituales «tres niveles, que correspondían a los niveles espirituales que la iglesia propugnaba»: el infierno, la tierra y el paraíso, que servían para enfatizar lecciones morales (Nieves 
Rivera y Henríquez Hureña 1990: 16). En la puesta en escena de Teatro El Público, si bien no se repite estrictamente esta construcción tripartita, existen también tres escalas por las cuales los actores suben o bajan. La transgresión del antiguo esquema reside en que muchas veces es en el nivel superior - el paraíso- donde los cuerpos desnudos de los actores se mueven de maneras más seductoras. Cabe entonces asumir que Carlos Díaz, rompiendo convenciones sociales y religiosas, coloca al placer en un plano paradisíaco, presentándolo como una fuerza superior que permitirá llevar las almas al grado más alto de sublimación. Otras analogías entre los procedimientos estéticos del teatro antiguo y los de Teatro El Público son posibles. Piénsese, por ejemplo, en los patios de comedias o corrales. Curiosamente, Carlos Díaz comenta sobre su puesta en escena en la sala el Trianón:

\begin{abstract}
El Trianón es como un corral, es una corrala, tenemos los mismos problemas que una corrala. Se hicieron muchas funciones de La Celestina sin aire acondicionado, los equipos de luces explotaban, el hacinamiento era brutal, en una época hubo perros y gallinas en los lados del teatro porque ahí viven particulares. Incluso desde antes, cuando yo hice El Público de Lorca, y en un ensayo entraban gallinas en el escenario. (Pino Más y Sarduy Zamora 2011: s-p)
\end{abstract}

\title{
Tras el texto y la escena: seguir con vida aún después del convivio
}

Muchos son los paralelismos y contradicciones que podríamos encontrar entre el montaje en cuestión y el original rojano, entre presente e historia, ficción y realidad, alma y cuerpo, verdad y falsa moral. Lo primero que salta a la vista tras esta investigación es la confirmación de lo que me dijo Carlos Díaz hace algún tiempo en una entrevista respecto a lo que debe ser la reescritura de un clásico: "yo creo que traer, mover, trabajar, violentar, hacer, festejar a esos textos clásicos en el público de hoy es un lujo para los artistas que lo interpretan y para el que ve la obra» (Pino Más y Sarduy Zamora, 2011: s-p). A partir de ese principio es indudable el éxito de una obra como La Celestina en la singladura profesional de Teatro El Público. La reescritura de la obra constituyó un éxito en tanto mantuvo un vínculo vivo con el pasado y permitió traer a la contemporaneidad las esencias de un tiempo que sigue guardando fuertes similitudes con el mundo del siglo xxi. Carlos Díaz, desde la cita postmoderna, el pastiche y la ironía, desde una severa provocación y una voluntad crítica, se apropia 
de los lenguajes de la práctica teatral y literaria española, como también de la cubana, para devolver, cual ejercicio artístico de postmodernidad, una sugerente propuesta formal que rompe con la tradición al tiempo que la rescata. En esa clave está su éxito, en conceder al público una historia que, una vez más, demuestra su vigencia y universalidad. Tal vez por eso La Celestina de Carlos Díaz «se convirtió en algo obligatorio para el público. Existían revendedores, historias con relación a la obra, venían los círculos de abuelos porque pensaban que la obra era en plan destape a donde podías venir y ver lo que tú quisieras en el escenario [...] fue un hito en el sentido que se hicieron 180 funciones y se vendían el piso, las paredes, la gente colgaba...» (Pino Más y Sarduy Zamora, 2011: s-p). Y es únicamente entonces cuando, en un verdadero proceso transitivo, un hito literario se convierte en un hito teatral, donde la escena trasciende el espacio del "convivio» para instalarse en el imaginario histórico y cultural de una isla. En ese ejercicio de transgresión el teatro se convierte igualmente en acontecimiento social y pasa a la memoria colectiva de la gente, más que como una efímera experiencia estética, como un grato recuerdo de vida. 


\section{Obras citadas}

Asenjo GonzÁlez, María. "La historia y la sociedad urbana en la lectura de La Celestina». Celestinesca 32 (2008): 13-35.

Barba, Eugenio. Obras escogidas. Vol. III. Ediciones Alarcos: La Habana, 2010.

CANO, Joel. "¡Que viva quien venza! La niñita querida: acto de creación». Tablas, Revista Cubana de las Artes Escénicas, número extraordinario, antología 1982-2002. La Habana, 2002.

DUBATI, Jorge. "De un mirador a otro: Dramaturgia(s) y ampliación del concepto de texto dramático: una conquista epistemológica de la teatralogía».Dram@teatro Revista Digital, Venezuela, 2005. <http://reliquiasideologicas.blogspot.com/2011/08/una-conclusion-particular.html>.

-. "Cultura teatral y convivio». s-f, s-p. <http://www.casa.cult.cu/publicaciones/revistaconjunto/136/dubatti.htm>.

Espinosa Mendoza, Norge. "El otro hilado de la Celestina». s-f. <http:// WWw.teatroelpublico.cult.cu/Extras/biblioteca/articulos/E1\%20 otro\%20hilado\%20de\%20la\%20Celestina.rar>.

-. Carlos Díaz: Teatro El Público: La trilogía interminable. Editorial Abril: La Habana, 2002.

Espinosa Mendoza, Norge y Abel González Melo, "Versión de La Celestina para el espectáculo de Teatro El Público». La Habana, 2002. <http:// www.teatroelpublico.cult.cu/ Extras/biblioteca/obras/Celestina.rar>.

Galarreta-Aima, Diana. "El tiempo en La Celestina: El deseo, el placer y el egoísmo como motivos de interpretación de la obra». Celestinesca 35 (2011): 43-66.

GARCía, Santiago: Teoría y práctica del teatro. Vol. I. Ediciones Alarcos: La Habana, 2008.

González Melo, Abel. «Nuestra Celestina. (Fragmentos)». Revista Digital La Jiribilla, 2002. <http://www.lajiribilla.cu/>.

Muguercia, Magaly. El cuerpo cubano: Teatro, performance y política en Cuba 1992- 2005. Buenos Aires: CELCIT, 2007.

Nieves Rivera, Dolores y Henríouez Hureña, Camila. Teatro y narrativa medieval. Editorial Pueblo y Educación: La Habana, 1990.

Pavis, Patrice: Diccionario del teatro. Editorial Paidós: Barcelona, 1998,

Pino MÁs, Dania del y Emeris SARduY Zamora. 2011. "No quiero realismo, quiero magia'. Entrevista realizada a Carlos Díaz». <http://www. cubaescena.cult.cu>.

RojAs, Fernando de. La Celestina o tragicomedia de Calisto y Melibea. Edición de Juan Alberto Álvarez. Editorial Pueblo y Educación: La Habana, 1977.

RojAs, Fernando de y "Antiguo Autor». La Celestina, Tragicomedia de Calisto y Melibea. Ed. Guillermo Serés Francisco J. Lobera, Paloma Díaz- 
Mas, Carlos Mota, Iñigo Ruiz Arzalluz y Francisco Rico. Crítica: Barcelona, 2000.

Teatro El Público. Página web <http://www.teatroelpublico.cult.cu>. 


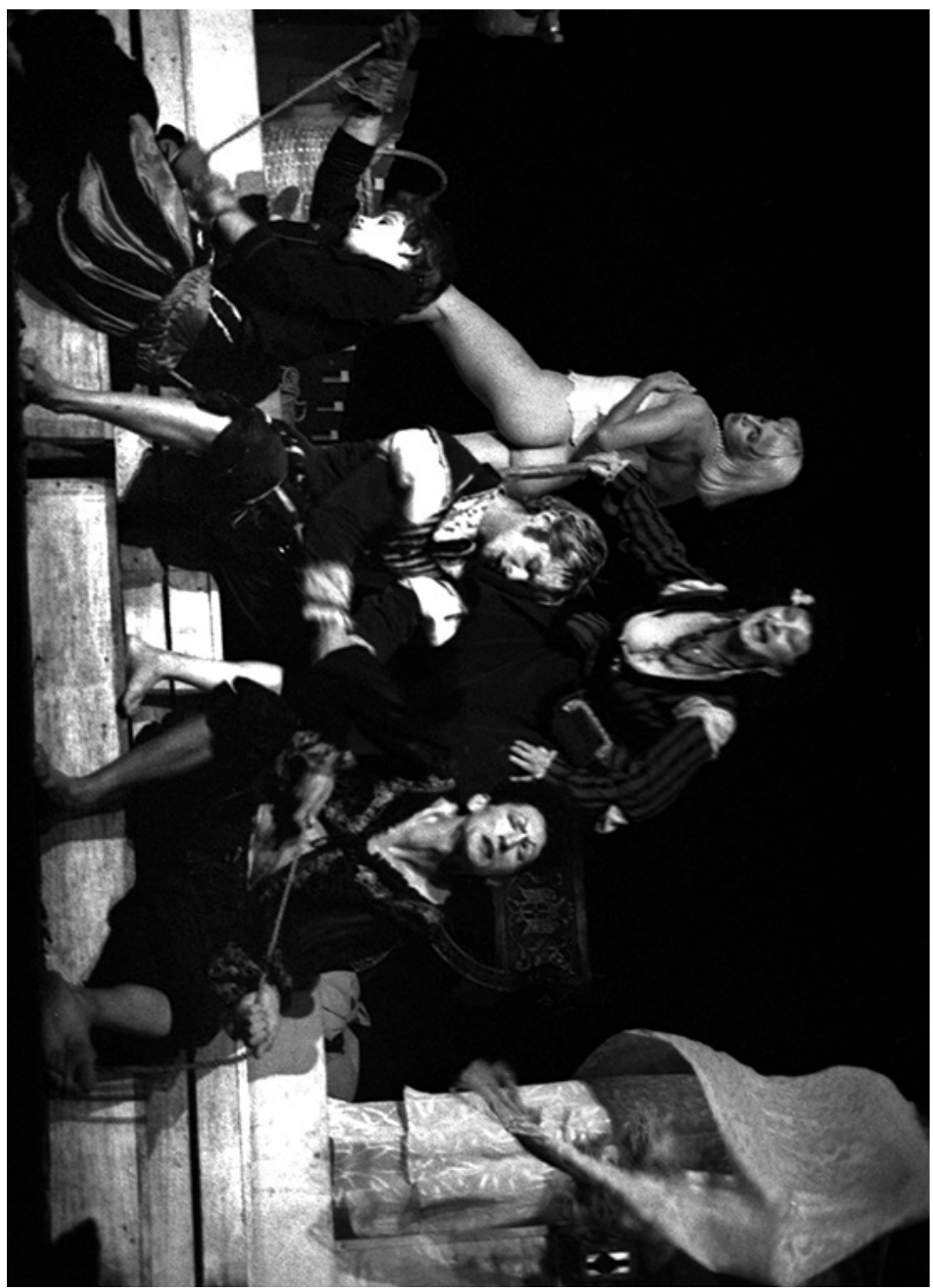

Montaje de La Celestina de Teatro El Público, La Habana, 2002. Fotos cortesía de Jorge Luis Baños 


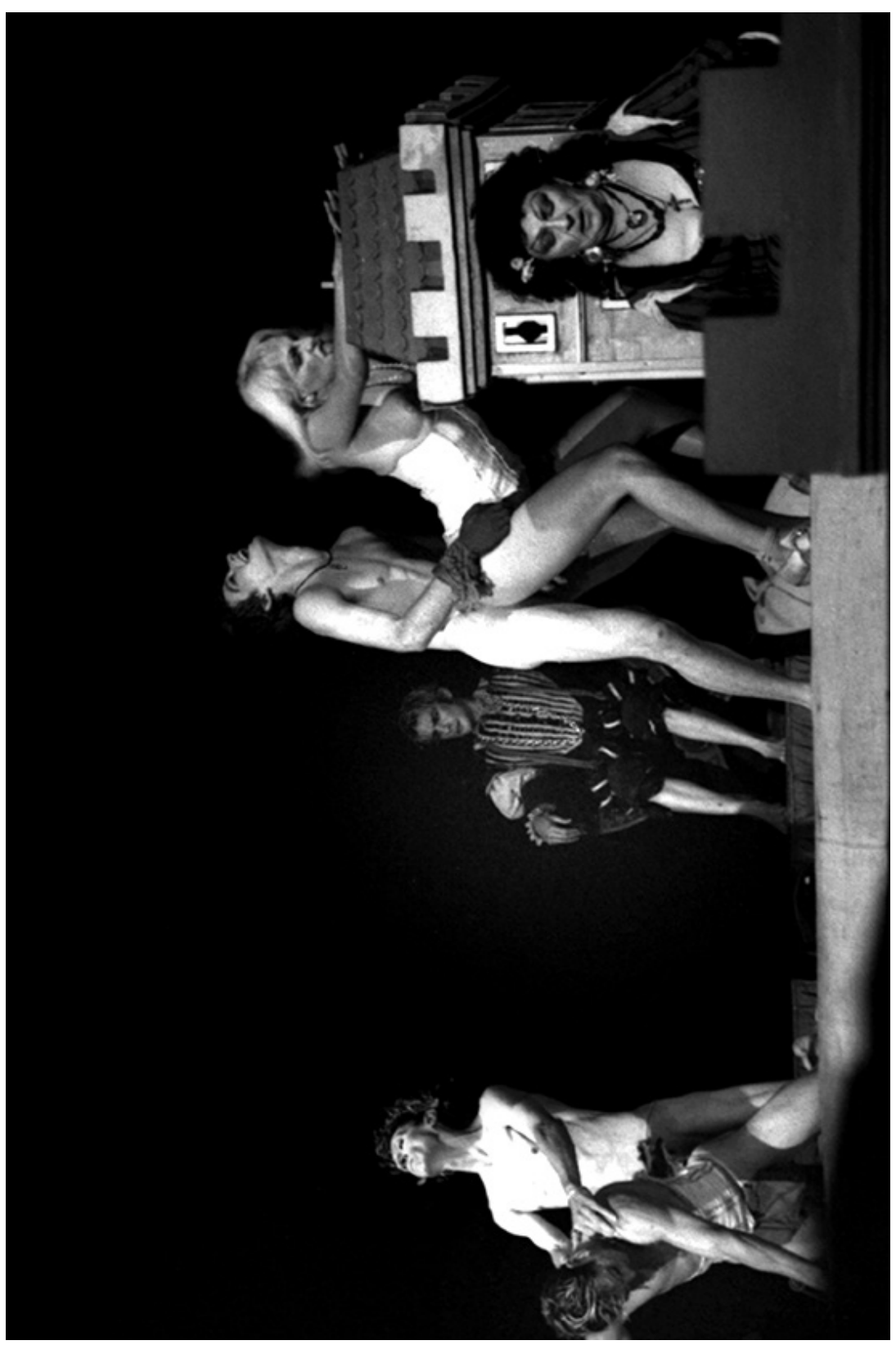

Montaje de La Celestina de Teatro El Público, La Habana, 2002. Fotos cortesía de Jorge Luis Baños 
Del Pino Más, Dania, «Paridades y conflictos: Analogía de dos mundos en La Celestina de Teatro El Público», Celestinesca 39 (2015), pp. 225-246.

\section{RESUMEN}

En 2002, la compañía Teatro El Público llevó a escena una adaptación de La Celestina que obtuvo un enorme éxito en Cuba. Este artículo examina cómo esta adaptación se sirvió de diversas técnicas dramáticas para darle al texto clásico de Rojas una serie de nuevos significados que eran muy pertinentes para el público cubano en las circunstancias históricas precisas de la isla en esos momentos. El texto original de la obra fue respetado en su mayoría, con la excepción de la supresión de los largos pasajes eruditos incluidos en los diálogos. Otros ingredientes de la producción, como el vestuario, la desnudez de algunos actores, una forma de actuar erotizada, la inclusión de piezas musicales de origen tradicional español y cubano, y la disposición espacial del escenario sirvieron para subrayar interesantes paralelismos y contrastes entre el mundo medieval en que se originó La Celestina y la situación de Cuba en la época.

palabras Clave: Adaptación dramática de La Celestina, Teatro El Público, Carlos Díaz Alfonso, Cuba.

\section{ABSTRACT}

Teatro E1 Público company staged an adaptation of Rojas' Celestina that was an enormous success in Cuba in 2002. This article examines how the adaptation deployed theatrical techniques to give the classical text new meanings that were especially adequate for Cuban audiences in that particular historical moment. The original text was respected, with the exception of the suppression of the long tirades dealing with erudite elements. Other ingredients of the production, such as the wardrobe, the nudity of some of the actors, eroticized acting, the addition of Spanish and Cuban music, and the physical disposition of the stage helped to highlight interesting parallelisms and contrasts between the medieval world in which Celestina was written and the situation of Cuba at that moment.

KeY words: Dramatic adaptation of Celestina, Teatro El Público, Carlos Díaz Alfonso, Cuba.

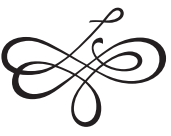

